\section{Effect of an Alcohol-Based Caries Detector on the Surface Tension of Sodium Hypochlorite Preparations}

\author{
Giampiero Rossi-Fedele', Andrea R. Guastalli²
}

'The University of Adelaide, Adelaide, South Australia, Australia ${ }^{2}$ Chemical Engineering Department, University of Barcelona, Barcelona, Spain

Correspondence: A/Prof. Giampiero Rossi-Fedele, The School of Dentistry, 15 Room 509, Oliphant Building, University of Adelaide, Adelaide, SA 5005, Australia. Tel: +61-88313-8139. e-mail: giampiero. rossi-fedele@adelaide.edu.au

\begin{abstract}
The purpose of this study was to evaluate the effect of an alcohol-based caries detector (Kurakay) on the surface tension of a conventional sodium hypochlorite $(\mathrm{NaOCl})$ preparation, and a product containing a surface-active agent (Chlor-XTRA). The surface tensions of the following solutions were tested: $\mathrm{NaOCl}$, a mixture of $\mathrm{NaOCl}$ and Kurakay 9:1 w/w, Chlor-XTRA, a mixture of Chlor-XTRA and Kurakay 9:1 w/w. Ten measurements per test solution were made at $20^{\circ} \mathrm{C}$, using an optical method called the "Pendant drop method", with a commercially available apparatus. The addition of Kurakay reduced the surface tension for $\mathrm{NaOCl}(\mathrm{p}<0.05)$ whilst no significant difference was detected for ChlorXTRA ( $>>0.05$ ). Statistically significant differences between the $\mathrm{NaOCl}$ and Chlor-XTRA groups were found $(p<0.05)$. The addition of an alcohol-based caries detector resulted in a reduction of the original surface tension values for $\mathrm{NaOCl}$ only. Taking into account the fact that mixtures of $\mathrm{NaOCl}$ and Kurakay have been used to assess the penetration of root canal irrigants in vitro, the related changes in surface tension are a possible source of bias.
\end{abstract}

Key Words: alcohol, caries detector, root canal irrigation, sodium hypochlorite, surface tension.

\section{Introduction}

Because of the inability to analyse commonly used irrigant penetration and distribution in the root canal system, researchers have recently relied on the radiographic tracing of radiopaque solutions (1-10), or in the observation of cleared teeth (1-3), using sodium hypochlorite ( $\mathrm{NaOCl})$ solutions made directly visible by the addition of dyes.

These experimental mixtures have been assumed a priori to behave like commonly used root canal irrigants. However, some of their physical properties, for example their surface tension, might have an influence on their penetration in experimental conditions. Surface tension is defined as the force per unit length exerted by one surface, and depends on the forces that attract molecules at the surface towards the bulk of a liquid (11). The cohesive forces between liquid molecules are responsible for the surface tension of the liquid. Considering a liquid drop, surface tension tends to minimize the surface area by making the drop spherical, while gravity deforms the drop by elongating a pendant drop or flattening a sessile drop (12). These effects are mathematically reflected in the Laplace equation of capillarity (13). Many conditions can affect the surface tension of liquids, such as temperature, surfactants, and the impurities of the liquid (11). Measuring surface tension thus becomes a crucial step in the development and quality control of formulations.

As the surface tension of a solution has a direct impact on its ability to spread in contact with a surface (14), the mixtures used to study dynamics of root canal irrigation should ideally present with values similar to those of commonly used root canal irrigants, to allow experimental results to be extrapolated to clinical practice. Sodium hypochlorite ( $\mathrm{NaOCl}$ ) mixtures with Kurakay Caries Detector (Kurakay) (Kurakay America Inc., New York, NY, USA), have been used in previous investigations (1-2). Accoding to the manufacturer, the Kurakay Caries Detector contains a mixture of dyes and propane-1,2-diol, with the latter component being an alcohol, and known to be incompatible with oxidizing agents. Chlorine-containing solutions such as $\mathrm{NaOCl}$ are oxidizing agents (15), and the addition of a different alcohol, ethanol, as a surface tension depressant increases the penetration of $\mathrm{NaOCl}$ containing mixtures in vitro (16). Therefore, a better understanding of the behaviour of $\mathrm{NaOCl}$ and Kurakay mixtures is necessary.

The aim of this study was to assess the effect of adding Kurakay on the surface tension of a conventional $\mathrm{NaOCl}$ preparation, and a product containing a surface-active agent.

\section{Material and Methods}

The surface tension of the mixtures was tested with an optical method, the so called "Pendant drop method", using the Phoenix 300 system (Goniometer and software by SEO-Surface Electro Optics, Suwon City, Gyunggido, South Korea), according to the manufacturer's instructions. In brief, the test liquid is pushed automatically (computercontrolled) out of a syringe needle until it almost detaches from the tip. Following this, the drop shapes are captured by an incorporated digital charged-coupled device camera. The surface tension of the liquid is automatically estimated 
by the apparatus. The equations describing the drop profile are derived from the Young-Laplace equation. Using the selected plane method the surface tension is rapidly obtained. This method calculates the surface tension by measuring the equatorial diameter, $d_{e}$, and the diameter $d_{s}$ of a pendant drop in a plane located at a distance $d_{e}$ from the tip of the droplet.

Surface tension (ST) can be mathematically calculated by the following equation:

$$
\mathrm{ST}=\left(\Delta \rho \cdot g \cdot \mathrm{d}_{\mathrm{e}}{ }^{2}\right) / \mathrm{H}
$$

Where $\Delta \rho$ is the density difference of fluids, $g$ is the gravitational acceleration, and $\mathrm{H}$ is the correction factor.

All measurements were carried out at $20^{\circ} \mathrm{C}$, in order to replicate the conditions of previous assays, as this value is often described as equivalent to "room temperature" (17). Distilled water was used for calibration prior to the assays. The test solutions were: $6 \% \mathrm{NaOCI}$ (Vista Dental Products, Racine, WI, USA), a mixture of $6 \% \mathrm{NaOCl}$ and Kurakay 9:1 $w / w$, Chlor-XTRA (Vista Dental Products), a mixture of ChlorXTRA and Kurakay 9:1 w/w. According to the manufacturer Chlor-XTRA has a 3-6\% active chlorine concentration, and contains Triton- $\mathrm{X}$, a non-ionic surfactant, of an undisclosed concentration.

Ten measurements per test solution were made. The mean and standard deviation were calculated for each group of 10 samples. Comparisons between the two groups were performed using a non-parametric test, the MannWhitney $\mathrm{U}$ test. The level of significance was set at 0.05 .

\section{Results}

The means and standard deviations of the surface tension of the groups are presented in Table 1. The MannWhitney $\mathrm{U}$ test showed statistically significant differences among the tested groups $(p<0.05)$, apart from between the Chlor-XTRA groups. The addition of Kurakay reduced the surface tension of $6 \% \mathrm{NaOCl}(p=0.004)$ whilst no significant difference was detected for Chlor-XTRA. Chlor-

Table 1. Surface tension values $(\mathrm{mN} / \mathrm{m} \pm \mathrm{SD})$ of the solutions tested.

\begin{tabular}{lc}
\hline Group $(\mathrm{N}=10)$ & Mean $(\mathrm{mN} / \mathrm{m}) \pm \mathrm{SD}$ \\
\hline $6 \% \mathrm{NaOCl}$ & $56.1 \pm 1.8^{\mathrm{a}}$ \\
$\mathrm{NaOCl}(90 \%)+K u r a k a y(10 \%) \mathrm{w} / \mathrm{w}$ & $36.7 \pm 3.5^{\mathrm{b}}$ \\
Chlor-XTRA & $16.9 \pm 2.0^{\mathrm{c}}$ \\
Chlor-XTRA $(90 \%)+K u r a k a y(10 \%) \mathrm{w} / \mathrm{w}$ & $18.2 \pm 1.6^{\mathrm{d}}$ \\
\hline
\end{tabular}

Groups identified by different superscript letters indicate statistically significant difference (Mann-Whitney $\mathrm{U}$ test). When comparing (a) with (b) the $p$ value was 0.004 ; when comparing (c) with (a) the $p$ value was 0.001 ; when comparing (d) with (b) the $p$ value was $<0.001$. SD: standard deviation
XTRA presented significantly lower surface tension values than $\mathrm{NaOCl}(p=0.001)$. Statistically significant differences were also found when comparing Chlor-XTRA+Kurakay and $\mathrm{NaOCl}+$ Kurakay $(\mathrm{p}<0.001)$.

An incidental finding of the investigation was colour loss for the mixtures occurring within minutes for $\mathrm{NaOCl}$, and several hours for Chlor-XTRA

\section{Discussion}

The addition of Kurakay to $\mathrm{NaOCl}$ led to a statistically significant reduction in surface tension, as expected. The increase in value for the Chlor-XTRA following the addition of Kurakay, while not statistically significant, may be explained because of the interactions between the different components within the mixtures, particularly the surfaceactive agent and the propane-1,2-diol. Regarding the discoloration and degradation observed in the preparations, we consider that this is probably due to the oxidation of the complex aromatic structure of the dye (acid red). This is significant from an experimental design standpoint, as it would make the mixtures less likely to be detected with the passing of time, thereby making it harder to observe their penetration, and introducing a possible source of bias. Therefore pilot studies looking into the stability of dyes mixed with the specific chlorine-containing preparations should be carried out prior to the performance of fullscale research. It is also necessary to consider the possible differences in the chemical characteristics of different batches of commercially available products.

Several methods have been developed to measure surface tension (du Nuoy ring, Wilhelmy plate, capillary rise, shape analysis of pendant drop, maximum bubble pressure, drop weight, amongst other) (18). The pendant drop technique measures surface tension with an optical tensiometer, based on the liquid's drop shape, which depends on the balance between interfacial and gravitational forces (12). It is commonly used to study physical properties in basic sciences and has been previously used in endodontic research (19).

The role of surface tension and other physical properties in root canal irrigant penetration and distribution need further understanding. Although several benefits have been suggested, the reduction in surface tension has been shown to improve penetration in the main canal only, by using experimental models that do not necessarily correspond to the naturally wet tooth, such as glass tubes and extracted teeth kept in unspecified storage conditions $(16,20,21)$. Though it has been traditionally suggested that surface tension influences the re-wetting of dry surfaces only (17), a recent investigation on non-dehydrated dentine has shown that the addition of a surfactant to $\mathrm{NaOCl}$ reduces its contact angle and surface tension (19). Therefore, surface 
tension might still be relevant in assays where teeth have been cleared, as they are normally imbibed in substances like methyl salicylate, and in vivo, as endodontically treated teeth present with an unbound water content of around $12 \%$ in weight (22). The surface tension of radiopaque solutions used to study root canal irrigation in vitro should be assessed with special care, as these are often used in teeth that might have lost their intrinsic moisture content during storage and preparation procedures. A similar situation will occur if either plastic or glassware is used. Other factors that influence the surface tension of liquids are their temperature and how smooth and clean the surface is (11). Therefore, experimental models should ideally aim to mimic the irregularities of the root canal surface and the normal body temperature. Clinicians and researchers should be aware that mixing materials, such as root canal medicaments or irrigants, can have chemical consequences that may lead to antagonistic interaction with subsequent negative effects in their performance (23-25).

In summary, the addition of an alcohol-based caries detector leads to a reduction in surface tension values for $\mathrm{NaOCl}$ alone, and there are no statistically significant differences for Chlor-XTRA, a $\mathrm{NaOCl}$ containing a surface-active agent.

\section{Resumo}

0 objetivo deste estudo foi avaliar o efeito de um detector de cárie com álcool (Kurakay) sobre a tensão superficial de um preparado convencional de hipoclorito de sódio ( $\mathrm{NaOCl}$ ) e um produto contendo um agente surfactante (Chlor-XTRA). Foram testadas as tensões superficiais das seguintes soluções: $\mathrm{NaOCl}$, uma mistura de $\mathrm{NaOCl}$ e Kurakay na proporção de 9:1 em peso, Chlor-XTRA e um mistura de Chlor-XTRA e Kurakay na proporção de 9:1 em peso. Dez medidas foram feitas com cada solução, a $20^{\circ} \mathrm{C}$, utilizando um método óptico chamado "Método da gota pendente" (Pendant drop method) usando aparelhos disponiveis. Adição do Kurakay reduziu a tensão superficial do $\mathrm{NaOCI}(p<0,05)$, mas não houve diferença significante para Chlor-XTRA $(p>0,05)$. Foram encontradas diferenças estatisticamente significantes entre os grupos $\mathrm{NaOCl}$ e Chlor-XTRA $(p<0,05)$. Adição de um detector de cárie com álcool resultou na diminuição do valor original da tensão superficial apenas para $\mathrm{NaOCl}$. Considerando que as misturas de $\mathrm{NaOCl}$ e Kurakay tem sido usadas para estudar a penetração in vitro dos irrigantes radiculares, as diferenças acima são uma possivel fonte de desvio nos resultados.

\section{References}

1. de Gregorio C, Estevez R, Cisneros R, Heilborn C, Cohenca N. Effect of EDTA, sonic, and ultrasonic activation on the penetration of sodium hypochlorite into simulated lateral canals: an in vitro study. J Endod 2009;35:891-895.

2. de Gregorio C, Estevez R, Cisneros R, Paranjpe A, Cohenca N. Efficacy different irrigation and activation systems on the penetration of sodium hypochlorite into simulated lateral canals and up to working length: an in vitro study. J Endod 2010;36:1216-1221.

3. de Gregorio C, Paranjpe A, Garcia A, Navarrete N, Estevez R, Esplugues EO, et al.. Efficacy of irrigation systems on penetration of sodium hypochlorite to working length and to simulated uninstrumented areas in oval shaped root canals. Int Endod J 2012;45:475-481.

4. Parente JM, Loushine RJ, Susin L, Gu L, Looney SW, Weller RN, et al. Root canal debridement using manual dynamic irrigation or the endovac for final irrigation in a closed system and an open system. Int Endod J 2010;43:1001-1012.

5. Tay FR, Gu L, Schoeffel GJ, Wimmer C, Susin L, Zhang K, et al.. Effect of vapor lock on root canal debridement by using a side-vented needle for positive-pressure irrigant delivery. J Endod 2010;36:745-750.

6. Munoz HR, Camacho-Cuadra K. In vivo efficacy of three different endodontic irrigation systems for irrigant delivery to working length of mesial canals of mandibular molars. J Endod 2012;38:445-448.

7. Vera J, Arias A, Romero M. Effect of maintaining apical patency on irrigant penetration into the apical third of root canals when using passive ultrasonic irrigation: An in vivo study. J Endod 2011;37:12761278.

8. Vera J, Arias A, Romero M. Dynamic movement of intracanal gas bubbles during cleaning and shaping procedures: the effect of maintaining apical patency on their presence in the middle and cervical thirds of human root canals - An in vivo study. J Endod 2012;38:200203.

9. Vera J, Hernández EM, Romero $M$, Arias $A$, van der Sluis LW. Effect of maintaining apical patency on irrigant penetration into the apical two millimetres of large root canals: an in vivo study. J Endod 2012;38:1340-1343.

10. Merino A, Estevez R, de Gregorio C, Cohenca N. The effect of different taper preparations on the ability of sonic and passive ultrasonic irrigation to reach the working length in curved canals. Int Endod J 2013;46:427-433.

11. Kane JW, Sternheim MM. Physics. 3rd ed. Brisbane: Wiley and Sons; 1998.

12. Yuan $Y$, Lee RT. Contact angle and wetting properties. In: Springer Series of Surface Sciences. Bracco G, Holst B (Editors). 1st ed. Sydney: Springer; 2013. p:3-34.

13. Saad SMI, Policova Z, Neumann WA. Design and accuracy of pendant drop methods for surface tension measurement. Colloids Surf $A$ Physicochem Eng Asp 2011;384:442-452.

14. Pécora JD, Guimarães LF, Savioli RN. Surface tension of several drugs used in endodontics. Braz Dent J 1991;2:123-127.

15. Rossi-Fedele G, Guastalli AR, Dogramacı E, Steier L, De Figueredo JAP. Influence of $\mathrm{pH}$ changes on chlorine-containing endodontic irrigating solutions. Int Endod J 2011;44:792-798.

16. Cunningham WT, Cole JS, Balekjian AY. Effect of alcohol on the spreading ability of sodium hypochlorite endodontic irrigant. Oral Surg 1982;54:333-335.

17. Jungbluth $H$, Peters $C$, Peters $O$, Sener B, Zehnder M. Physicochemical and pulp tissue dissolution properties of some household bleach brands compared with a dental sodium hypochlorite solution. J Endod 2012;38:372-375.

18. Berg JC. An introduction to interfaces and colloids: The bridge to nanoscience. 1st ed. Singapore: World Scientific Publishing Co; 2010.

19. Bukiet $F$, Couderc $C$, Camps J, Tassery H, Cuisinier F, About I, et al.. Wetting properties and critical micellar concentration of benzalkonium chloride mixed in sodium hypochlorite. J Endod 2012;38:1525-1529.

20. Cameron JA. The effect of fluorocarbon surfactant on the surface tension of the endodontic irrigant. Aust Dent J 1986;31:364-368.

21. Rossi-Fedele G, Prichard JW, Steier L, Figueiredo JAP. The effect of surface tension on the clinical performance of sodium hypochlorite in endodontics. Int Endod J 2013;46:492-498.

22. Papa J, Cain C, Messer HH. Moisture content of vital vs endodontically treated teeth. Endod Dent Traumatol 1994;10:91-93.

23. Athanassidis M, Jacobsen N, Parashos P. The effect of calcium hydroxide on the steroid component of Ledermix and Odontopaste. Int Endod J 2011;44:1162-1169.

24. Athanassidis M, Jacobsen N, Nassery K, Parashos P. The effect of calcium hydroxide on the antibiotic component of Odontopaste and Ledermix paste. Int Endod J 2013;46;530-537.

25. Rossi-Fedele G, Dogramacı E, Guastalli AR, Steier L, Figueiredo JAP. Antagonistic interactions between sodium hypochlorite, chlorhexidine, EDTA and citric acid. J Endod 2012;38:426-431.

Received July 23, 2014 Accepted December 11, 2014 